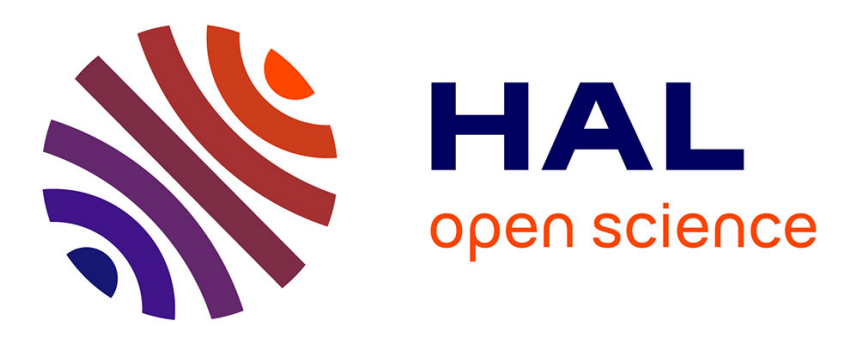

\title{
The inheritance of fruit colour in apple (Malus pumila Mill.)
}

Allan G. White, Yves Lespinasse

\section{To cite this version:}

Allan G. White, Yves Lespinasse. The inheritance of fruit colour in apple (Malus pumila Mill.). Agronomie, 1986, 6 (1), pp.105-108. hal-00884854

\section{HAL Id: hal-00884854 https://hal.science/hal-00884854}

Submitted on 1 Jan 1986

HAL is a multi-disciplinary open access archive for the deposit and dissemination of scientific research documents, whether they are published or not. The documents may come from teaching and research institutions in France or abroad, or from public or private research centers.
L'archive ouverte pluridisciplinaire HAL, est destinée au dépôt et à la diffusion de documents scientifiques de niveau recherche, publiés ou non, émanant des établissements d'enseignement et de recherche français ou étrangers, des laboratoires publics ou privés. 


\title{
The inheritance of fruit colour in apple (Malus pumila Mill.)
}

\author{
Allan G. WHITE \& Yves LESPINASSE $\left({ }^{*}\right)$ \\ Department of Scientific and Industrial Research, Research Orchard, Goddard Lane, Havelock North, \\ New Zealand. \\ (*) Station de Recherches d'Arboriculture fruitière, Beaucouzé, F 49000 Angers
}

SUMMARY

Studies on two apple seedling progenies from crosses between a common female parent and two different male parents suggested that red fruit colour was determined by two dominant complementary genes. Blush and red colour did not appear to segregate independently ; a single dominant gene for blush linked to one of the genes for red colour is proposed. Red pigmentation was found only in the layer of skin originating from LII.

Additional key words : Skin colour, hybridization.

Deux descendances de pommier impliquant un parent femelle commun sont étudiées quant à l'hérédité de la couleur de l'épiderme du fruit. Les ségrégations obtenues nécessitent deux gènes complémentaires dominants pour rendre compte de la distribution du caractère, couleur rouge de l'épiderme ; ces ségrégations ne satisfont pas l'hypothèse classique d'un seul gène dominant. L'aspect rouge uniforme et la présence de stries rouges sur fond jaune ne sont pas deux caractères indépendants : l'un des gènes proposés pour expliquer la couleur rouge serait lié à un troisième gène dominant pour conduire à l'aspect rouge uniforme. La couleur rouge foncé a pour origine les cellules épidermiques issues de la couche histogénique L II.

Mots clés additionnels : Couleur de l'épiderme, hybridation.

\section{INTRODUCTION}

Many studies indicate the presence of a major dominant gene for red colour in the skin of apple fruit (WILCOX \& ANGELO, 1936 ; ALDERMAN \& LANTZ, 1938 ; Wellington \& Howe, 1944 ; AlSTON \& WATKINS, 1973 ; BROWN, 1975 ; HANIUDA et al., 1977 ; KARNATZ, 1979 ; SCHMIDT \& KRUGER, 1983). LESPINASSE et al. (1984) have proposed from a study on one population that yellow colour may be the result of two complementary genes, $\mathrm{A}+\mathrm{B}$, and that red colour the result of one of these genes, A or B. With this hypothesis it was also possible to account for the results of KARNATZ (1979) who found red fruit colour in $20 \%$ of a selfed 'Golden Delicious' progeny.

Some authors have reported striping to be dominant over blushed colour in a simple segregation pattern

(1) Ce travail a été réalisé à la Station d'Arboriculture fruitière de l'I.N.R.A., à Angers, lors d'un séjour de 6 mois effectué par le premier auteur.
(WILCOX \& ANGELO, 1936 ; KLEIN, 1958 ; BROWN, 1975 ) and others (KARNATZ, 1979) have described a complex segregation.

The skin of the apple fruit has been shown to arise from the histogenic layers LI and LII of the apical meristem (EINSET, 1952; DAYTON, 1969). The epidermis derives from the superficial layer LI and the subepidermal layers of the hypodermis from the LII (GILBERT, 1963 ; PRATT et al., 1975). Each layer expresses red pigmentation independently of the other (MISIĆ \& TESOVIĆ, 1971 ; PRATT et al., 1972 ; PRATT et al., 1975).

\section{MATERIALS AND METHODS}

The progenies used in this study resulted from two crosses made in 1979 ; 'TNB 34-37' $\times$ 'Gloster 69' and 'TNB 34-37' $\times$ 'Cloden'. 'TNB 34-37' is a selection from the scab resistance programme at INRA Angers (fig. 1). 


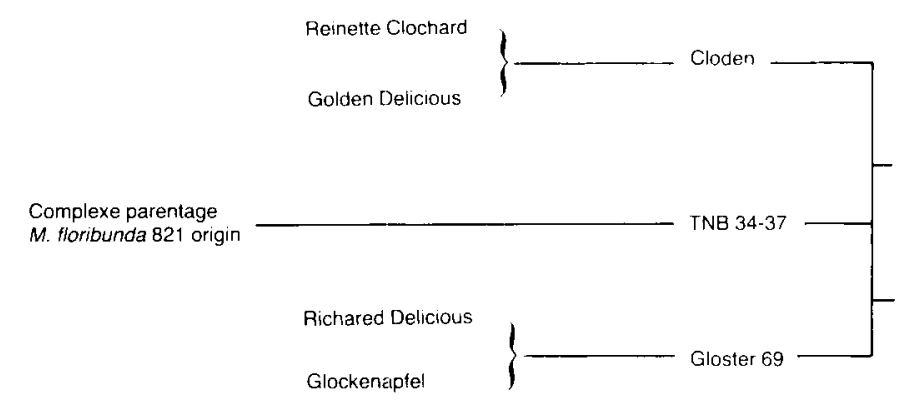

Figure 1

Parentage of the experimental progenies.

Origine des descendances étudiées.

The germination rate for both populations was in the order of $95 \%$ (table 1). The young seedlings were inoculated in the glasshouse with a suspension of apple scab spores (Venturia inaequalis (Cke.) Wint.) at the threeleaf stage. $68 \%$ of the 'TNB 34-37' $\times$ 'Gloster 69 ' and $60 \%$ of the 'TNB 34-37' $\times$ 'Cloden' progeny were screened out as being scab susceptible.

The seedlings were then screened in the nursery for susceptibility to powdery mildew (Podosphaera leucotricha (Ell. et Ev.) Salm.). Both populations were screened for stunted growth at the nursery stage. No seedlings were discarded from the 'TNB 34-37' $\times$ 'Gloster 69' population, but $24 \%$ of the 'TNB 3437 ' $\times$ 'Cloden' population were discarded for this reason. No other screening was applied to either population and we assumed that selection pressures were the same in both cases.

From the original populations, $118(14 \%)$ 'TNB 3437 ' $\times$ 'Gloster 69' and $93(8 \%)$ 'TNB 34-37' $\times$ 'Cloden' seedlings were selected for planting in the orchard.

Observations were carried out on the fruit of all those seedlings which set fruit in $1984 ; 112(95 \%)$ 'TNB 34-37' $\times$ 'Gloster 69' and $80(86 \%)$ 'TNB 3437 ' $\times$ 'Cloden'.

At maturity fruit colour was classified into four categories ; (a) more than $50 \%$ blushed red ('Gloster 69' type) ; (b) more than $50 \%$ striped red ('TNB 34-37' type); (c) yellow (including light red sunblush) ; and (d) yellow-green ('Cloden' type).

One well coloured fruit was selected from each seedling and a section of the epidermis examined under the microscope using the method described by DAYTON (1959) to determine whether the red pigmentation was in the epidermal or hypodermal layers.

\section{RESULTS AND DISCUSSION}

Red pigment was found in the hypodermal layers of both 'TNB 34-37' and 'Gloster 69' type seedlings. However, 'Gloster 69' carried red pigment in both epidermal and hypodermal layers while 'TNB 3437' had red pigment in the hypodermis only. Sunblushed fruit had sparsely distributed red pigmented cells within the blushed areas, in either the epidermis or hypodermis, seldom in both. It was not possible to determine if red pigment from sunblush was occurring in the hypodermis of the heavily pigmented 'TNB 34-37' and 'Gloster 69' type seedlings. The fruit from the 'TNB 34-37' $\times$ 'Gloster 69' cross were easily classified into three distinctive categories ; 'TNB 34-37' type : $23 \%$, 'Gloster 69 ' type : $48 \%$, and yellow (including sunblush) : $29 \%$. There was a marked discontinuity between the three groups, particularly between red and yellow, but a limited gradation did exist within each group.

The fruit from the 'TNB 34-37' $\times$ 'Cloden' cross were also easily classified into 'TNB 34-37' type : $31 \%$, yellow (including sunblush) : $46 \%$ and 'Cloden' type : $23 \%$. As with 'TNB 34-37' $\times$ 'Gloster 69' there was a marked discontinuity between the red and nonred categories, but there was no clear distinction between the yellow and yellow-green ('Cloden') categories (table 2).

The proportions of seedlings with red fruit to those with non-red fruit were 3:1 in the 'TNB 34-37' $\times$ 'Gloster 69' cross and 1:3 for the 'TNB 34-37' $\times$ 'Cloden' cross. 'Thus, if both red parents are heterozygous, red colour segregated in the 'TNB 34-37' $\times$ 'Gloster 69' progeny according to the single dominant gene hypothesis of ALSTON \& WATKINS (1973) but this model cannot be applied to the 'TNB 34-37' $\times$ 'Cloden' progeny where a segregation of $1: 1$ would be expected. The observed ratios can however both be explained by two complementary dominant genes for red colour A and B which are freely segregating. A yellow pigment is produced by A or B alone and the yellow phenotype does not just arise from the absence of red. Yellow-green colouration is the expression of a double recessive genotype and results from the absence of a yellow pigment rather than the augmentation of the green pigmentation.

This explanation differs from that of TREBUSHENKO (1939) who proposed two genes for red colour throughout the plant designating one $F$, as a basic gene,

TABLE 1

Pre-selection of apple progenies in glasshouse and nursery for resistance to disease and vigour.

Sélection des descendances en serre et en pépinière pour la résistance aux maladies et la vigueur.

\begin{tabular}{|c|c|c|c|c|c|c|c|c|c|}
\hline Cross & $\begin{array}{l}\text { No. of } \\
\text { Seeds }\end{array}$ & Germination & $\%$ Germ. & $\begin{array}{c}\text { Susceptible } \\
\text { Apple } \\
\text { Scab }\end{array}$ & $\begin{array}{l}\text { Stunted } \\
\text { Growth }\end{array}$ & $\begin{array}{l}\text { Planted in } \\
\text { Nursery }\end{array}$ & $\begin{array}{l}\text { Susceptible } \\
\text { Powdery } \\
\text { Mildew }\end{array}$ & $\begin{array}{l}\text { Planted in } \\
\text { Orchard }\end{array}$ & $\begin{array}{l}\% \text { of sdlgs } \\
\text { planted in } \\
\text { orchard }\end{array}$ \\
\hline $\begin{array}{l}\text { TNB } 34-37 \times \\
\text { Gloster } 69\end{array}$ & 831 & 783 & 94.2 & 532 & 0 & 251 & 133 & 118 & 15.1 \\
\hline $\begin{array}{l}\text { TNB } 34-37 \times \\
\text { Cloden }\end{array}$ & 1159 & 1108 & 95.6 & 664 & 268 & 176 & 83 & 93 & 8.4 \\
\hline
\end{tabular}


TABLE 2

Segregation for fruit colour in apple progenies.

Ségrégation pour la couleur de l'épiderme chez les 2 descendances étudiées.

\begin{tabular}{|c|c|c|c|c|c|c|}
\hline Cross & $\begin{array}{c}+50 \% \text { Red Blush } \\
\text { Gloster } 69 \text { type }\end{array}$ & $\begin{array}{c}+50 \% \text { Red Striped } \\
\text { TNB } 34-37 \text { type }\end{array}$ & $\begin{array}{l}\text { Yellow } \\
\text { and sunblush }\end{array}$ & $\begin{array}{c}\text { Yellow/ } \\
\text { Green }\end{array}$ & $x^{2}$ & $\begin{array}{c}\mathbf{P} \\
\text { (approx.) }\end{array}$ \\
\hline TNB 34-37 × Gloster 69 & $\begin{array}{l}\text { obs }: 54 \\
\text { exp : } 56 \\
\text { ratio : } 2\end{array}$ & $\begin{array}{r}26 \\
28 \\
1\end{array}$ & $\begin{array}{r}32 \\
28 \\
1\end{array}$ & $\begin{array}{l}0 \\
0 \\
0\end{array}$ & 0.786 & 0.6 \\
\hline TNB 34-37 $\times$ Cloden & 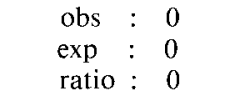 & $\begin{array}{r}25 \\
20 \\
1\end{array}$ & $\begin{array}{r}37 \\
40 \\
2\end{array}$ & $\begin{array}{r}18 \\
20 \\
1\end{array}$ & 1.675 & 0.4 \\
\hline
\end{tabular}

and the other, $\mathrm{M}$ as a gene specifically for anthocyanin, a dominant allele of each being necessary for anthocyanin production.

The segregation patterns for red colour found in the populations in this study appear similar to those reported elsewhere (KLEIN, 1958 ; PRATT et al., 1975), and it is possible to explain their results using two complementary gene mechanisms more satisfactorily than with a single dominant gene for red colour.

The relationship between flavonols and anthocyanin pigmentation in apples was raised by LESPINASSE et al. (1984), but it is well known in other species (ALSTON, 1959 ; HARBOURNE, 1967 ; VAN BUREN, 1970 ; BRAUN, 1976). Yellow colour is the expression of a complex of flavonols and carotenoids. Quercetin glycoside has been found to be present at high concentrations on the sun exposed side of 'Golden Delicious' (WELLINGTON \& HOWE, 1944). This flavonol appears to precede cyanidin galactoside anthocyanins in the biosynthetic pathway (HARBOURNE, 1967). Cyanidin- 6-galactoside is the major red pigment in the apple skin (SUN \& FRANCIS, 1967 ; FARAGHER \& BROHIER, 1984). If the biosynthetic pathway for anthocyanin in apples, follows that of other higher plants, then this hypothesis is possible.

The two populations chosen for this study do not conform to the previous genetic hypothesis of LESPINASSE et al. (1984), but both proposals are similar in that they require interaction between two genes and they suggest a relationship between yellow and red pigments.

Several loci may exist for red colour with the observed differences in inheritance pattern being explained by the expression of different loci in different crosses.

A second possibility is that the loci for red colour are multiallelic and their expression changing with different recombinations. Thus, in some cases they may act as single genes or pseudogenes (ALSTON, 1959) and in others in a more complex manner.

TABLE 3

Genetic hypothesis explaining fruit colour and type of colour in apple progenies.

Hypothèse génétique formulée pour la couleur de l'épiderme.

\begin{tabular}{|c|c|c|c|}
\hline$T N B 34$ & $-37: \frac{A}{a} \cdot \frac{B}{b} \cdot \frac{l}{l}$ & SLOSTER $69: \frac{A}{A} \cdot \frac{B}{b} \cdot \frac{L}{l}$ & $C L O D E N: \frac{a}{a} \cdot \frac{b}{b} \cdot \frac{l}{l}$ \\
\hline$A+B$ & Red & rouge & \\
\hline$A$ or $B$ & Yellow & jaune & \\
\hline$a b$ & Yellow green & jaune vert & \\
\hline$L$ & blush - L linked to $B$ in coupling phase & rouge homogène - $L$ & couplage \\
\hline & stripe & rouge strié. & \\
\hline
\end{tabular}

\begin{tabular}{|c|c|c|c|c|}
\hline Gloster 69 & A.B.I & A.b.1 & a.B.I & a.b.l \\
\hline A.B.L. & $\begin{array}{l}\frac{\mathrm{A}}{\mathrm{A}} \cdot \frac{\mathrm{B}}{\mathrm{B}} \cdot \frac{\mathrm{I}}{\mathrm{L}} \\
\text { red blush }\end{array}$ & $\begin{array}{l}\frac{A}{A} \cdot \frac{b}{B} \cdot \frac{1}{L} \\
\text { red blush }\end{array}$ & $\begin{array}{l}\frac{a}{A} \cdot \frac{B}{B} \cdot \frac{1}{L} \\
\text { red blush }\end{array}$ & $\begin{array}{l}\frac{\mathrm{a}}{\mathrm{A}} \cdot \frac{\mathrm{b}}{\mathrm{B}} \cdot \frac{1}{\mathrm{~L}} \\
\text { red blush }\end{array}$ \\
\hline A.b.l & $\begin{array}{l}\frac{A}{A} \cdot \frac{B}{b} \cdot \frac{1}{1} \\
\text { red stripe }\end{array}$ & $\begin{array}{l}\frac{A}{A} \cdot \frac{b}{b} \cdot \frac{1}{1} \\
\text { yellow }\end{array}$ & $\begin{array}{l}\frac{a}{A} \cdot \frac{B}{b} \cdot \frac{1}{1} \\
\text { red stripe }\end{array}$ & $\begin{array}{l}\frac{a}{A} \cdot \frac{b}{b} \cdot \frac{1}{1} \\
\text { yellow }\end{array}$ \\
\hline $\mathrm{TN}$ & & & & \\
\hline Cloden & A.B.I & A.b.l & a.B.I & a.b.l \\
\hline a.b.l & $\begin{array}{l}\frac{\mathrm{A}}{\mathrm{a}} \cdot \frac{\mathrm{B}}{\mathrm{b}} \cdot \frac{1}{\mathrm{l}} \\
\text { red stripe }\end{array}$ & $\begin{array}{l}\frac{A}{a} \cdot \frac{b}{b} \cdot \frac{l}{l} \\
\text { yellow }\end{array}$ & $\begin{array}{l}\frac{a}{a} \cdot \frac{B}{b} \cdot \frac{1}{1} \\
\text { yellow }\end{array}$ & $\begin{array}{l}\frac{a}{a} \cdot \frac{b}{b} \cdot \frac{1}{1} \\
\text { yellow/green }\end{array}$ \\
\hline
\end{tabular}


The segregation of the 'TNB 34-37' $\times$ 'Gloster 69' progeny into parental type groups for red colour and blush or stripe suggests a strong linkage effect between red colour and blush. Further support for this is that in the 'TNB 34-37' $\times$ 'Cloden' progeny all the red fruit are of the striped or 'TNB 34-37' type. In the first case 'Gloster 69' type blush is dominant over 'TNB 34-37' type stripe in a ratio $2: 1$. A possible interpretation is that there is a single gene dominant for blush, $\mathrm{L}$, which is strongly linked in 'Gloster 69' to one of the complementary genes for red colour, $\mathrm{B}$, in the coupling phase (table 3 ). The proposed genotypes for the parents in this study are therefore: 'TNB 34-37', AaBbll ; 'Gloster 69', AABbLl, and 'Cloden', aabbll. These genotypes are also consistent with the known parentage of these three varieties (fig. 1).

We assume that 'Gloster 69' has inherited its colour characteristic A.B.L. from its parent 'Richared Delicious' (PRATT et al., 1972 ; PRATT et al., 1975) which carried a factor for extensive red in LII. 'Cloden' ('Golden Delicious' $x$ 'Reinette Clochard') has both parents with yellow-green pigmentation. The parentage of 'TNB 34-37' is complex and includes both yellow and red types.

Red colour is one of the most commercially important characters in apple. Slight variations in colour intensity, tone, and distribution are significant in the market place. It is of great value to the breeder therefore to understand the mechanism of inheritance precisely in order to exert some control over this factor in his breeding programmes.

The proposed genotypes and genetic interactions in this study are attempts to interpret the empirical results of two specific hybridizations and as such are limited, however, they do support some other studies which indicate there is a wider range of possibility for the mechanism of colour inheritance than has generally been considered (PRATT et al., 1972, LESPINASSE et al., 1984). Further studies, including biochemical analysis of the synthetic pathways for pigment in the apple skin are required before a precise understanding of colour inheritance can be gained.

Reçu le 28 janvier 1985. Accepté le 9 septembre 1985.

\section{REFERENCES}

Alderman D. C., Lantz H. L., 1938. Apple breeding inheritance and statistical studies on the fruits of crossbred seedlings with Antonovka parentage. Prac. Am. Soc. hortic. Sci., 36, 279-283.

Alston F. H., Watkins R., 1973. Apple breeding at East Malling. Proc. Eucarpia Fruit Section Symp. V. Top Fruit Breeding Canterbury, Sept. 11-14, 14-29.

Alston R. E., 1959. Physiology and the inheritance of anthocyanin pattern. Genetica 30, 261-277.

Braun A., 1976. L'hérédité des anthocyanes florales. Année Biologique 15, 294-328.

Brown A. G., 1975. Breeding for specific characters, 1, 3-57. In : J. Janick, J. N. Moore: «Advances in fruit breeding ». Purdue University Press.

Dayton D. F., 1959. Red color distribution in apple skin. Proc. Am. Soc. hortic. Sci., 74, 72-81.

Dayton D. F., 1969. Genetic heterogeneity in histogenic layers of apple. J. Am. Soc. hortic. Sci., 94, 592-595.

Einset J., 1952. Spontaneous polyploidy in cultivated apples. Proc. Am. Soc. hortic. Sci., 75, 291-302.

Faragher J. D., Brohier R. L., 1984. Anthocyanin accumulation in apple skin during ripening : regulation by ethylene and phenylalanine ammonialyase. Scientia Hortic., 22, 89-96.

Gilbert A. H., 1963. A study of skin development in the McIntosh apple. Proc. Am. Soc. hortic. Sci., 82, 45-50.

Haniuda T., Yoshida Y., Tsuchiya S., 1977. Studies on the inheritance of fruit characteristics of apple: II. Inheritance of skin colour. Bull. Fruit Tree Res. Stat., Morioka, Japan, 4, 1-11.

Harborne J. B., 1967. Comparative biochemistry of the flavonoids, Chpt 8, 250-271. Inheritance and biosynthesis of flavonoids in plants, Acad. Press.

Karnatz A., 1979. Progeny analysis of self-fertilization in apple cultivars, some results. Proc. Eucarpia Fruit Section, Angers, 29-39.
Klein L. G., 1958. The inheritance of certain fruit characters in the apple. Proc. Am. Soc. hortic. Sci., 72, 1-14.

Lespinasse Y., Lespinasse J. M., Ganne B., 1985. Inheritance of two agronomical characters in the apple tree (Malus pumila Mill) : Compact type habit and fruit colour. Acta hortic., 159, Tree fruits and nuts breeding, 35-47.

Misić P. D., Tesović Z. V., 1971. Anthocyanin colour distribution in the skin of Cox's Urange Pippin apple and its dark red sports. Hortic. Res., 11, 161-165.

Pratt C., Way R. D., Ourecky D. H., 1972. Irradiation of colour sports of Delicious and Rome apples. J. Am. Soc. hortic. Sci., 97 (2), 268-272.

Pratt C., Way R. D., Einset J., 1975. Chimeral structure of red sports of Northern Spy apple. J. Am. Soc. hortic. Sci., 100 (4), 419422.

Schmidt H., Kruger J., 1983. Fruit breeding at the Federal Research Centre for horticultural plant breeding, Ahrensburg/Holstein. Acta Horticulturae, 140, Fruit Breeding, 15-33.

Sun B. H., Francis F. J., 1967. Apple anthocyanins : identification of cyanidin - 7 - arabinoside. J. Food Sci. 32, 647-649.

Trebushenko P. D., 1939. (Inheritance of anthocyanin coloration in apple tree. A contribution to the problem of breeding red-fruited and red fleshed varieties of apples.) Dokl. Akad. Nauk SSSR, 23, 939-943 (in Russian).

Van Buren J., 1970. Fruit phenolics. In : A. C. Hulme : « The biochemistry of fruits and their products ". Vol. 1, Chapter 11, 269300 (Ed. A. C. Huime) Academic press.

Wellington R., Howe G. H., 1944. The performance of seedlings derived from selfing and crossing the McIntosh apple. Proc. Am. Soc. hortic. Sci., 44, 273-279.

Wilcox A. N., Angelo E., 1936. Apple breeding studies I. Fruit color. Proc. Am. Soc. hortic. Sci., 33, 108-113. 